DOI: 10.32844/2222-5374-2020-106-4-1.11

УДК: 342.922

Комірчий П. О.,

доктор юридичних наук, доцент

\title{
ФОРМИ ТА ПРОЦЕДУРИ КАДРОВОГО ЗАБЕЗПЕЧЕННЯ ПУБЛІЧНОЇ СЛУЖБИ В ПРАВООХОРОННІЙ СФЕРІ
}

У статті зазначається, що в сучасних умовах принципово важливого значення набуває місце кадрового забезпечення публічної служби у правоохоронній сфері, яке досліджується крізь призму останніх змін в адміністративному законодавстві України, новим етапом реформи правоохоронної системи нашої держави. Обгрунтовано, що організація публічної служби в сучасних умовах передбачає значну кількість взаємопов'язаних форм і процедур кадрового забезпечення. До відповідних форм належать: визначення стратегії організаційно-штатної роботи; навчально-підготовча робота; добір і відбір персоналу; призначення на посаду та заміщення посад, розстановка кадрів; забезпечення проходження служби. Встановлено, що форми кадрового забезпечення окреслюють межі відповідних кадрових процедур. Встановлена та охарактеризована специфіка процедур кадрового забезпечення, що реалізуються в межах зазначених форм кадрового забезпечення (наприклад, у межах стратегічної організаційноштатної роботи здійснюють процедури розрахунку кадрової чисельності публічної служби, позитивного стимулювання цієї служби тощо). Теоретично доведено, що правильне поєднання доступних форм і процедур кадрового забезпечення сприяє реальному підвищенню ефективності функціонування правоохоронного органу на підставі якісного використання потенціалу працівників без збільшення затрат часу й ресурсів на їх утримання. Визначено, що кадрове забезпечення публічної служби у правоохоронній сфері України - це елемент управління кадрами органів публічної служби у правоохоронній сфері, що $\epsilon$ нормативно упорядкованою системою взаємопов'язаних елементів, які знаходяться між собою у стійких адміністративно-правових відносинах стосовно кадрового забезпечення, $в$ межах яких забезпечується їх функціонування як єдиного цілого. Зроблено висновок, що форми і процедури кадрового забезпечення публічної служби в правоохоронній сфері України, власне як і будь-який інший складний сощіальноправовий феномен у площині функціонування суб'єктів публічної адміністрації, підлягає ретельному адміністративно-правовому врегулюванню, в межах якого нормотворцем визначаються особливі правові вимоги до здійснення кадрового забезпечення публічної служби відповідної сфери. Тобто до існування кадрового забезпечення публічної служби в правоохоронній сфері у статичному та динамічному вигляді на нормативному рівні висувається велика кількість вимог, спрямованих на належне укомплектування суб'єкта публічної адміністрації якісними кадрами, уможливлення ефективного та раціонального керування кадровим забезпеченням й підвищення рівня однозначності цього явища. Особливе місце 
серед цих нормативних вимог займають нормативні вимоги до організаційної структури кадрового забезпечення публічної служби у правоохоронній сфері.

Ключові слова: персонал, кадрове забезпечення, публічна служба, форми та процедури, правоохоронна сфера, Національна поліція.

Актуальність теми. Починаючи 3 реформ у Національній поліції України з 2015 р. активізувались численні перетворення у структурі системи суб'єктів публічної адміністрації та в самій концепції здійснення публічного адміністрування, що було ознаменовано здійсненням численних реформ, зокрема у судових органах, державній службі, органах прокуратури, створенні Державного бюро розслідувань. Дані події призвели до відповідних нових фундаментальних змін у структурі та характері загроз означеному розвиткові. Не $\epsilon$ виключенням із цього правила також i справедливі намагання сьогочасної України впровадити комплекс перетворень у сфері кадрового забезпечення публічної служби у правоохоронній сфері України, що $\epsilon$ досить складним й узгодженим процесом, який має виявлятись в практичній діяльності у передбачених чинним адміністративним законодавством способах, порядку, формах та процедурах. При цьому слід звернути увагу на те, що досі форми кадрового забезпечення публічної служби у зазначеній сфері не були предметом комплексного дослідження, в якому б враховувались усі актуальні зміни в адміністративному законодавстві України, що $\epsilon$ особливою актуальною проблемою вітчизняної науки адміністративного права. Безумовно, ця проблема також $є$ й важливою практичною проблемою. Це пояснюється надзвичайною актуальністю кадрового забезпечення в умовах численних адміністративно-правових перетворень, які відбуваються в нашій державі, та наявними факторами загрози національній безпеці, корупція у правоохоронних органах та в структурі суб'єктів публічного адміністрування загалом, котрі певною мірою мінімізуються унаслідок належного функціонування органів публічної служби в правоохоронній сфері. Загострює цю проблему не завжди ефективна діяльність публічних службовців у правоохоронній сфері, що переважною мірою пов'язано з тим, що у відповідних органах публічної служби нашої держави не завжди на належному рівні здійснюється процес кадрового забезпечення. Ускладнює вирішення цього питання той факт, що в сучасній юридичній думці не існує узгодженого щодо форм та процедур розуміння кадрового забезпечення публічної служби в правоохоронній сфері.

Таким чином, кадрове забезпечення у загальному контексті є окремою галуззю кадрової політики, що підпорядкована меті цієї політики й органічно взаємопов'язана з іншими її спрямуваннями. У цьому сенсі кадрове забезпечення публічної служби у правоохоронній сфері України $\epsilon$ феноменом, що виявляється у статичному та динамічному аспекті

Отже, в сучасних умовах принципово важливого значення набуває дослідження форм та процедур кадрового забезпечення у правоохоронній сфері, зокрема Національній поліції України.

Аналіз останніх досліджень і публікацій. Дослідження у даній сфері були предметом наукових досліджень багатьох вчених. Суттєвий внесок у вивчення та розроблення форм та процедур кадрового забезпечення у правоохоронній сфері здійснено у дослідженнях В.Б. Авер'янова, 


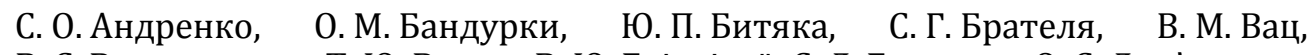
В. С. Венедиктова, Т. Ю. Витко, В. Ю. Грітчіної, С. Д. Гусарєва, О. С. Дем'яненка,

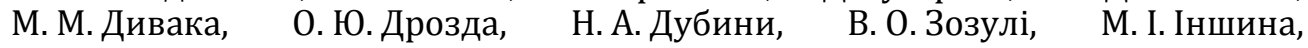
Т. Є. Кагановської, Р. А. Калюжного, А. М. Клочка, В. І. Козицького, T. О. Коломоєць, В. В. Колпакова, А. Т. Комзюка, С. Ф. Константінова, O. В. Копана, О. Є. Користіна, С. І. Корсуна, А. Є. Крищенка, О. В. Кузьменко, М. В. Лошицького, В. Я. Малиновського, А. В. Перепелиці, О. В. Петришина, Р. А. Сербина, В. В. Сокуренка, А. А. Стародубцева, В.Я. Тація, В. М. Тетері, Ю. М. Топчія, Ю. Г. Фаєр, Н. Л. Шевченко, В. Г. Яцуби та ін.

Проте останні зміни до чинного законодавства та реформування правоохоронних органів активізували увагу вчених до вивчення та необхідності більш детального розгляду форм та процедур кадрового забезпечення у правоохоронній сфері, зокрема у Національні поліції України.

Наукова новизна. Наукова новизна одержаних результатів полягає в тому, що в умовах структурно-функціональних змін у системі державного управління, зокрема форми та процедури кадрового забезпеченні у правоохоронній сфері є одним із найважливіших у адміністративно-правовій науці комплексних досліджень сучасної концепції публічної служби. В ході проведеного дослідження було проаналізовано усталені наукові підходи до розуміння сутності форм і процедур кадрового забезпечення публічної служби в правоохоронній сфері як встановленого адміністративним законодавством публічно-правового порядку, який сприяє впорядкуванню діяльності публічних службовців і формуванню якісного кадрового складу.

Метою статті $\epsilon$ дослідження форм та процедур кадрового забезпечення публічної служби у правоохоронній сфері України, з'ясування юридичної сутності структури форм кадрового забезпечення публічної служби в правоохоронній сфері нашої держави. Ця мета дотягатиметься шляхом критичного аналізу наявних наукових досліджень українських вчених, які вже досліджували проблеми кадрового забезпечення публічної служби, а також шляхом дослідження чинного законодавства України в частині, що унормовує процес кадрового забезпечення публічної служби загалом та правоохоронної сфери зокрема.

Виклад основного матеріалу. Кадрове забезпечення $\epsilon$ нормативно врегульованою, особливою та цілеспрямованою управлінською діяльністю уповноважених осіб у структурі органів публічної служби у правоохоронній сфері, а також процесом і сукупністю відносин, у межах яких реалізовується комплекс форм, методів, процедур і заходів уможливлення належного функціонування органів публічної служби у правоохоронній сфері шляхом вчасного та оптимального укомплектування цих органів якісними кадрами. Кадрове забезпечення $\epsilon$ галуззю кадрової політики, що має системний характер, власну структуру, принципи та функції, безпосередньо спрямовані на діяльність і процес з належним чином здійснюваного укомплектування органів публічної служби у правоохоронній сфері професійно підготовленими, кваліфікованими кадрами (з урахуванням особливостей проходження служби у відповідних органах);

Кадрове забезпечення публічної служби у правоохоронній сфері України - це елемент управління кадрами органів публічної служби у правоохоронній сфері, що $\epsilon$ нормативно упорядкованою системою 
взаємопов'язаних елементів, які знаходяться між собою у стійких адміністративно-правових відносинах стосовно кадрового забезпечення, в межах яких забезпечується їх функціонування як єдиного цілого.

Персонал органу публічної служби в правоохоронній сфері України - це постійний чи тимчасово працюючий кадровий склад відповідного органу публічної служби. Особи, що входять до кадрового апарату, маючи відповідний рівень правосуб'єктності та перебуваючи в державно-службових (чи лише трудових) відносинах, виконують службово-трудову (чи лише трудову) функцію в структурі цього органу публічної служби на підставі чинного законодавства й контрактів (договорів).

Адміністративно-правовий статус персоналу органів публічної служби в правоохоронній сфері - це системна сукупність взаємозалежних нормативно визначених адміністративно-правових властивостей кадрового складу органу публічної служби в правоохоронній сфері як суб'єкта адміністративного права. Цей статус персоналу охоплює такі елементи: обсяг правосуб'єктності кандидата на посаду, що дозволяє надати адміністративно-правовий статус і зберегти його після призначення на посаду; порядок зайняття посади (працевлаштування); права й обов'язки персоналу (цим елементом охоплено: права та обов'язки людини і громадянина; трудові права й обов'язки; загальні права та обов'язки державних службовців; загальні права й обов'язки державних службовців відповідного органу; безпосередні права та обов'язки державного службовця відповідного органу, що закріплено посадовими інструкціями або функціональними обов'язками); обмеження персоналу; принципи і гарантії, передбачені законодавством для персоналу; юридична відповідальність персоналу (особливості її настання, перебігу та припинення).

Форми діяльності органів публічної служби в правоохоронній сфері України - це зовнішнє практичне вираження дій i рішень публічних службовців органів публічної служби у відповідній сфері, які вони вчиняють (приймають) на підставах, у межах повноважень і в спосіб, що передбачені чинним законодавством України, 3 метою забезпечення та здійснення покладених на них завдань у правоохоронній сфері держави.

3 огляду на спрямування завдань органів публічної служби в правоохоронній сфері, форми їхньої діяльності можна поділити на такі групи:

1) правові (діяльність, здійснювана в межах професійної юридичної діяльності), а саме: нормотворча, правозастосовна, установча, контрольнонаглядова, виконавча;

2) неправові, зокрема службові наради, консультації, рекомендації, роз'яснення, психологічна допомога, економічне стимулювання.

Методами діяльності органів публічної служби в правоохоронній сфері України $\epsilon$ сукупність передбачених законодавством прийомів, засобів і способів досягнення мети в правоохоронній сфері - виконання поставлених перед органом завдань (охорона конституційного ладу, суверенітету й територіальної цілісності держави, захист громадян; запобігання та протидія протиправній діяльності; забезпечення та розвиток системи правоохорони).

Ці методи поділяють на такі групи:

1) загальні (притаманні майже всім органам публічної служби), зокрема методи переконання, заохочення (стимулювання), примусу; 
2) пізнавально-програмувальні (наукові, статистичні тощо);

3) організаційно-регулювальні (застосування способів і прийомів організації та регулювання різних об’єктів діяльності з метою їх оптимізації), зокрема адміністративні (організаційні, розпорядчі), тощо.

Зазначимо, що кадрове забезпечення публічної служби в правоохоронній сфері нашої держави, є складним узгодженим процесом, який має виявлятись у практичній дійсності в передбачених чинним адміністративним законодавством способах, порядку та формах. Причому слід звернути увагу на те, що донині форми і процедури кадрового забезпечення публічної служби в досліджуваній сфері ще не були предметом комплексного дослідження, у яких би враховувались усі актуальні зміни в чинному адміністративному законодавстві України, що $\epsilon$ особливою актуальною проблемою вітчизняної науки адміністративного права. Ця проблема, безперечно, також є важливою практичною проблемою. На це вказує надзвичайна актуальність кадрового забезпечення в умовах численних адміністративно-правових перетворень, які відбуваються в нашій державі, та активізації численних загроз національній безпеці, котрі мінімізуються завдяки належному функціонуванню органів публічної служби в правоохоронній сфері.

Як слушно 3 цього приводу зауважив А. А. Іванищук, кадрове забезпечення залежить від стабільності політичних і соціально-економічних процесів у державі, тому цілком закономірно воно має відповідати демократичним перетворенням i «встигати» за нововведеннями й реформами в політично-економічній системі країни [1, с. 188].

Форми i процедури кадрового забезпечення публічної служби в правоохоронній сфері України, власне як і будь-який інший складний соціальноправовий феномен у площині функціонування суб'єктів публічної адміністрації, підлягає ретельному адміністративно-правовому врегулюванню, в межах якого нормотворцем визначаються особливі правові вимоги до здійснення кадрового забезпечення публічної служби відповідної сфери. Тобто до існування кадрового забезпечення публічної служби в правоохоронній сфері у статичному та динамічному вигляді на нормативному рівні висувається велика кількість вимог, спрямованих на належне укомплектування суб'єкта публічної адміністрації якісними кадрами, уможливлення ефективного та раціонального керування кадровим забезпеченням й підвищення рівня однозначності цього явища. Особливе місце серед цих нормативних вимог займають нормативні вимоги до організаційної структури кадрового забезпечення публічної служби у правоохоронній сфері.

Форми кадрового забезпечення загалом $\epsilon$ спеціальним виявом такої юридичної конструкції, як форми адміністративно-правового забезпечення. На переконання Д. В. Мамчура, і 3 цим цілком можна погодитись, в адміністративно-правовому контексті формами забезпечення $\epsilon$ зовнішнє вираження певних дій, які здійснюються відповідними суб'єктами в межах наданих їм повноважень і можуть вважатися належною підставою для настання чи ненастання правових наслідків [2, с. 10]. Натомість в аспекті кадрового забезпечення, на думку С. Г. Гаспарян, яка розглядає означене питання в межах кадрового забезпечення судово-експертних установ, відповідними формами кадрового забезпечення $\epsilon$ «зовнішнє вираження 
діяльності 3 кадрового забезпечення судово-експертних установ, яке відображає його сутність, цілі, завдання, зміст та особливості: відбір і добір кандидатів на посади експертів окремих судово-експертних установ, професійну підготовку експертів (навчання, підвищення кваліфікації, професійна атестація експертів), оцінювання та контроль, просування по службі, мотивацію, соціальне забезпечення, правове виховання» [3, с. 10].

3 огляду на вказане, передусім слід з'ясувати сутнісний зміст та видову структуру форм кадрового забезпечення публічної служби у правоохоронній сфері.

Як видається, цікавою і поряд з тим не менш дискусійною є точки зору С. А. Гальонкін, який з цього приводу зауважив, що в загальному значенні форма забезпечення $\epsilon$ виявом відповідної забезпечувальної діяльності (процесу, процедур), будучи конкретними групами дій уповноважених державно-владних органів, які є допустимими, з точки зору їх легальності, та доцільними і необхідними до застосування в межах тих правовідносин, що виникли [4, с. 103]. У загальному значенні сутність форм забезпечення полягає у визначенні меж і змісту забезпечувальної діяльності (процесу, процедур).

Отже, форми кадрового забезпечення публічної служби в правоохоронній сфері - це об’єктивні конструктивні вияви взаємоузгодженого функціонування складових механізму кадрового забезпечення публічної служби у відповідній сфері, що відображають сутність, завдання, зміст й особливості належного функціонування цих органів, а також спрямовані на перетворення закріплених у нормативно-правових актах вимог щодо здійснення кадрового забезпечення в практичній площині. У цьому контексті процедури кадрового забезпечення публічної служби в правоохоронній сфері $\epsilon$ встановленими адміністративним законодавством публічно-правовими порядками, якими регламентують діяльність публічної служби у відповідній сфері й формують високоефективний та кваліфікований кадровий склад цієї публічної служби, а також забезпечують права, свободи й законні інтереси суб'єктів кадрового забезпечення шляхом здійснення компетентним суб'єктом комплексу дій і заходів, прийняття та виконання управлінських рішень у відповідних межах.

Як видається з цього приводу, не можна не погодитись із слушними висновками вчених про те, що форми кадрового забезпечення публічної служби в правоохоронній сфері $\epsilon$ об'єктивним виявом відповідної забезпечувальної діяльності, у зв'язку з чим можна дійти висновку, що ці форми окреслюють певні процедури кадрового забезпечення (кадрові процедури), а види цих процедур обумовлюють видову структуру вказаних форм. Як слушно з цього приводу зазначив В. М. Тетеря, розглядаючи основні форми кадрового забезпечення Національної поліції на регіональному рівні, цими формами є: 1) добір на посаду поліцейського- складання тесту професійного спрямування, тесту на загальні вміння та навички, проходження психологічного тесту, співбесіди та за погодженням 3 кандидатом - тестування на поліграфі; 2) обстеження претендентів на поліцейську службу (низка медичних досліджень, серед яких профілактичний огляд, тест на реакцію на рухомий об'єкт, перевірка простої зорово-моторної реакції, критичної частоти світлових мерехтінь, тест- 
система для проведення експрес-діагностики стану алкогольного сп'яніння тощо); 3) прийняття та призначення на службу - присяга, контракт чи наказ; 4) просування по службі та переміщення - тест загальних навичок, тест за конкретним напрямом роботи; тест-оцінка на знання професійної етики тощо; 5) оцінювання та контроль- перевірка фізичної підготовки, атестаційний лист; 6) громадський контроль кадрового забезпечення та діяльності Національної поліції України - «гаряча лінія» [5, с. 16-17].

Як видається, цікавими і поряд з тим не менш дискусійними є точки зору інших вчених щодо форм кадрового забезпечення у правоохоронній системі. 3 цього приводу, С. О.Андренко влучно називає такі основні форми кадрового забезпечення органів внутрішніх справ: 1) форми профорієнтаційної роботи (тренінги, конференції, форуми, презентації, виступи, друковані видання, опитування тощо); 2) форми організаційноштатної роботи (розрахунок нормативів кадрової чисельності, планування потреби в кадрах, оптимізація кадрової структури, розрахунок навантаження кадрів, форми організації кадрових служб і форми управління кадрами тощо); 3) правові форми укладення, зміни й припинення контрактів; 4) форми підготовки, добору та розстановки кадрів (присвоєння спеціальних звань, форми навчання та підготовки кадрів (денна, заочна, дистанційна), форми залучення та відбору кадрів - іспити, тестування, атестування, робота 3 кадровим резервом, конкурсний відбір тощо); 5) форми кадрового забезпечення в процесі проходження служби в органах внутрішніх справ (робота з кадровим резервом, факторний аналіз кадрового забезпечення, структурний аналіз особового складу, облік кадрів, форми оцінювання ефективності роботи працівників, ротація кадрів, внутрішні конкурси, перерозподіл функціональних обов'язків, суміщення посад, форми забезпечення службового просування кадрів, форми матеріального, соціального та інших видів забезпечення тощо); 6) форми підвищення кваліфікації, професіоналізму та перепідготовки кадрів (міжнародний обмін, стажування, щорічне оцінювання, атестація, курси, тренінги тощо); 7) форми наставництва, виховання та соціально-психологічного забезпечення кадрів; 8) форми стимулювання службової активності кадрів, укріплення законності, відповідальності й службової дисципліни в діяльності кадрів (заохочення, подяки, занесення на дошку пошани, проведення конкурсів «Кращий працівник» тощо, штрафні санкції за порушення дисципліни тощо) [6, с. 11].

Вартий уваги підхід до розуміння переліку форм кадрового забезпечення, запропонований В. Ю. Грітчіною. Авторка цілком доречно називає ці форми «формами проведення кадрових процедур» та в контексті Національної поліції України відносить до них такі форми: 1) форму добору на посаду поліцейського (професійний тест, тест загальних навичок, психологічний тест, співбесіда, тестування на поліграфі); 2) обстеження кандидатів на службу в поліції (первинний профілактичний огляд, тестсистеми для експрес-діагностики стану алкогольного, наркотичного сп'яніння); 3) прийняття на службу поліцейського та призначення на посаду (накази, контракт, присяга); 4) переміщення та просування по службі (тест оцінки благонадійності та професійної етики, тест загальних навичок, спеціалізований тест за відповідним напрямом, тест на поліграфі); 5) оцінювання та контролю (атестаційний лист, перевірка стану фізичної 
підготовки: біг на різні дистанції, підтягування; забезпечення зв'язку апарату Національної поліції України із суспільством за допомогою «гарячої лінії») [7, с. 13].

Однак, на наше переконання, слід зазначити, що попри прогресивність зазначених позицій 3 приводу розуміння переліку форм кадрового забезпечення публічної служби, структурування видів форм цього забезпечення та відповідних процедур потребує комплексного вдосконалення, яке би враховувало найбільш повно комплекс форм i процедур кадрового забезпечення. Отже, форми кадрового забезпечення публічної служби в правоохоронній сфері нашої держави можуть бути структуровані лише на підставі дослідження сутності процедур кадрового забезпечення публічної служби у відповідній сфері, окреслення яких сприяє становленню наукової думки про форми відповідного забезпечення.

Досліджуючи форми кадрового забезпечення, слід мати на увазі, що процедури кадрового забезпечення - це особливий вид процедур, які мають очевидне юридичне значення (передусім юридичних процедур), а отже, передусім необхідно уточнити дефініцію поняття «процедура».

Концептуальну позицію 3 означеної проблематики сформулювала Н. В. Галіцина, яка зазначила, що 3 правової точки зору процедурою $\epsilon$ «регламентований юридичною нормою порядок дій або регулювання відповідних суспільних відносин у сфері правозастосування» $[8$, с. 166].

У межах комплексного підходу до розуміння поняття «процедура» український вчений А. В. Басов процедурою пропонує вважати: 1) сукупність засобів і методів здійснення державної влади; 2) офіційно встановлений порядок реалізації закріплених у законодавстві правил і норм; 3) діяльність органів публічного управління щодо вирішення індивідуальних адміністративних справ, результатом якої $\epsilon$ прийняття адміністративного акта чи укладання адміністративного договору [9, с. 20].

Вивчаючи процедури кадрового забезпечення судово-експертних установ України, С.Г.Гаспарян, дійшла висновку, що відповідними процедурами $\epsilon$ «врегульований нормами законодавчих i підзаконних нормативно-правових актів порядок здійснення комплексу дій і заходів, прийняття та виконання рішень управлінського й організаційного характеру в межах передбачених форм кадрового забезпечення судово-експертних установ України (добору, підготовки та підвищення кваліфікації кадрового складу судово-експертних установ, просування по службі тощо), спрямований на забезпечення прав, свобод і законних інтересів суб'єктів кадрового забезпечення судово-експертних установ та впорядкування їхньої діяльності» [3, с. 14].

3 огляду на це, можна погодитись з думкою В. М. Тетері, який зауважив, що адміністративна процедура кадрового забезпечення Національної поліції (передусім на регіональному рівні) - це встановлений законодавчими нормами порядок діяльності органів кадрового забезпечення 3 метою формування високоефективного та кваліфікованого кадрового складу. У цьому контексті адміністративні процедури кадрового забезпечення класифікують за такими критеріями: 1) за ініціатором - за поданням та втручальні; 2) за наслідками - позитивні й негативні; 3) процедури відповідно до стадії кадрового забезпечення - прогнозування, планування, 
комплектація, ротація, стимулювання, мотивація тощо; 4) за призначенням організаційні, управлінські та контрольні [5, с. 17].

В. Ю.Грітчіна, критично аналізуючи кадрове забезпечення Національної поліції, вказує на те, що кадрова процедура в Національній поліції України $є$ встановленою відповідно до норм адміністративного законодавства впорядкованою послідовністю дій щодо добору, навчання, підготовки, розстановки кадрів, проходження служби, атестації, мотивації, просування та переміщення по службі, звільнення, які $\epsilon$ елементами управління кадрами та в сукупності становлять процес кадрового забезпечення Національної поліції, що здійснюється з метою комплектації поліції висококваліфікованими професіоналами для ефективного виконання покладених на неї функцій і завдань [7, с. 10-11].

У свою чергу Н.Г.Плахотнюк влучно наголошував на потребі врахування того, що за своєю суттю кадрові процедури в органах державного управління відповідають сутності процедур управління персоналом, а отже, ці поняття можна використовувати як синонімічні [10, с. 171-172].

3 огляду на зазначене, можна дійти закономірної думки, що процедури кадрового забезпечення публічної служби в правоохоронній сфері України - це встановлені адміністративним законодавством України публічно-правові порядки, котрими впорядковується діяльність публічної служби у відповідній сфері й формується високоефективний та кваліфікований кадровий склад цієї публічної служби, а також забезпечуються права, свободи та законні інтереси суб'єктів кадрового забезпечення шляхом здійснення компетентним суб'єктом комплексу дій та заходів, прийняття та виконання управлінських рішень у межах передбачених форм кадрового забезпечення публічної служби у правоохоронній сфері.

Як видається з нашого дослідження, слід зазначити, що процедури кадрового забезпечення в загальному значенні можуть бути приватноправовими та публічно-правовими. Причому, з огляду на те, що службові відносини за участю публічного службовця є публічно-правовими (тому, як це відображено у п. 2 ч. 1 ст. 19 КАСУ [11], й спори з приводу прийняття громадян на публічну службу, їі проходження, звільнення 3 публічної служби - це публічно-правові спори), можна стверджувати, що юридичними процедурами 3 ознаками публічних процедур також $\epsilon$ процедури кадрового забезпечення публічної служби. У зв'язку з цим, необхідно звернути увагу на те, що ознаками публічно-правової процедури, як слушно з цього приводу зауважив А. Б. Грищук, є такі їі особливі риси: а) встановлення та врегулювання процедури законом як публічним правовим актом; б) встановлення законом юридичної форми результату публічної процедури; в) неможливість здійснення публічної процедури однією особою, навіть такою, яка має публічно-правовий статус; г) участь у вчиненні публічної процедури за бажанням громадян, або участь у вчиненні публічної процедури інститутів публічної влади [12, с. 34].

Таким чином, відповідно до логіки послідовності здійснення управлінських дій стосовно реалізації процедур кадрового забезпечення публічної служби, цілком можливо структурно виділити наступні форми кадрового забезпечення публічної служби в правоохоронній сфері. 
1. Форми стратегічної організаційно-штатної роботи з кадрового забезпечення публічної служби у правоохоронній сфері. Загальновідомо, що від чисельності працівників, котрі виконують певні функціональні обов'язки, залежить статус підрозділу, кількість керівників і рівнів керування, можливість спеціалізації, особливості організації праці, а отже, штатна чисельність держоргану в правоохоронній сфері- найважливіша характеристика цього органу, його підрозділів та один із факторів, що визначає параметри організаційної структури [13, с.33]. У цьому контексті важливе значення має організаційно-штатна робота як особлива група форм кадрового забезпечення публічної служби, яка охоплює низку процедур кадрового забезпечення, що можуть здійснюватися в межах цих форм.

Водночас В. I. Козицький, аналізуючи сутнісний зміст організаційноштатної роботи в системі МВС України, зауважив, що нею $є$ управлінська діяльність, спрямована на оптимальний розподіл та ефективне використання штатної чисельності, удосконалення структури органів і підрозділів, дотримання штатної дисципліни, ощадливе витрачання коштів, що виділяються органам і підрозділам для виконання покладених на них завдань та функцій, на основі широкого використання наукових методів і підходів [14, с. 70].

Таким чином, аналізуючи концептуальні підходи вчених до розуміння форм організаційно-штатної роботи 3 кадрового забезпечення публічної служби, а також положення чинного законодавства України про держслужбу, публічну службу в органах правопорядку, зважаючи на існуючу практику кадрового забезпечення публічної служби у правоохоронній сфері, доходимо думки, що розглядувана група форм кадрового забезпечення практично охоплює всі наявні форми кадрового забезпечення (це також прослідковується в підходах вчених щодо викладення переліку вказаних форм), адже вони тією чи іншою мірою стосуються організаційної кадрової роботи.

2. Навчально-підготовчі форми кадрового забезпечення публічної служби у правоохоронній сфері. Як з цього приводу правильно зробив висновок український науковець А. А.Стародубцев, публічна служба у правоохоронній сфері виконує відповідальне й непросте завдання щодо захисту суспільства від злочинних посягань. На думку вченого, успішне виконання цього завдання залежить від готовності та спроможності кожного працівника на належному рівні виконувати свої професійні обов'язки [15, с. 180]. Водночас необхідно мати на увазі, що вже на етапі завершення навчання та вибору професії, як 3 цього приводу слушно зазначив С. І. Корсун, особистість потрапляє в стресові умови вибору професії: перед особистістю постає нелегке завдання: яку обрати професію серед численного переліку, куди спрямувати свої сили, щоб отримати саме ті знання та навички, що дадуть змогу отримати задоволення від професійної діяльності та присвятити своє життя обраному фаху [16, с. 303]. Певна річ, мінімізує відповідну проблему для майбутніх публічних службовців у правоохоронній сфері навчання у відомчих навчальних закладах. Крім того, вітчизняні вчені припускають, що найкраще публічних службовців у правоохоронній сфері можуть підготувати саме відомчі заклади вищої освіти. Зокрема, О.С.Дем'яненко зауважив, що відомча освіта дає змогу охопити 
саме ту сферу знань, з якою безпосередньо буде пов'язана майбутня діяльність [17, с. 177].

3 огляду на вказане, слід зауважити, що навчально-підготовчі форми кадрового забезпечення публічної служби у правоохоронній сфері виявляються в таких формах кадрового забезпечення:

1) добір кандидатів на навчання до закладів вищої освіти із специфічними умовами навчання;

2) особлива форма перебігу процесу навчання;

3) завершення процесу навчання, позитивні результати якого передбачають подальший розподіл випускника до державного органу, у якому він буде проходити службу.

Цікавими з позиції досліджуваної у цій роботі проблематики, є погляди В. В. Сокуренко, який зауважив, що процес відбору кандидатів на навчання до закладів вищої освіти із специфічними умовами навчання є першим етапом підготовки поліцейських, а отже, від того, яким чином цей етап буде впорядковано на рівні відповідних нормативно-правових актів (зокрема прописано специфічні умови відбору кандидатів і вступу), безпосередньо залежить рівень професійної підготовки майбутніх поліцейських та формування їхніх фахових компетентностей. Зокрема, до закладів вищої освіти зі специфічними умовами навчання, які здійснюють підготовку кадрів для МВС України, поліцейських і військовослужбовців Національного гвардії України, на сьогодні процес добору, направлення та зарахування кандидатів на навчання здійснюється відповідно до вимог чинного законодавства, нормативних актів Міністерства освіти і науки України, МВС України та загалом дозволяє сформувати якісний склад абітурієнтів, які в майбутньому будуть здатні на високому рівні виконувати професійні обов'язки у сфері захисту прав і свобод громадян, забезпечення публічної безпеки та протидії злочинності $[18$, с. 44$]$.

Аналізуючи сутнісний зміст навчально-підготовчих форм кадрового забезпечення публічної служби у правоохоронній сфері, можемо дійти висновку, що відповідними кадровими процедурами, серед іншого, є добір кандидатів на навчання у відомчому закладі вищої освіти, а також направлення та зарахування цих кандидатів; навчання та екзаменування студентів (курсантів, слухачів) тощо.

3. Форми добору та відбору публічних службовців у правоохоронній сфері Украӥни. На сьогодні, як зазначають В.С.Венедіктов і М.І.Іншин, комплектування органів виконавчої влади всіх рівнів висококваліфікованими кадрами, спроможними забезпечити економічний і соціальний розвиток держави, набуло першочергового значення [19, с. 4], що є цілком закономірним, з огляду на значущість дисциплінованої, ефективної та раціональної діяльності публічних службовців у підтриманні життєздатності держави та виконання покладених на неї функцій.

Водночас слід ураховувати також те, що на сучасному етапі розвитку суспільства завдання, які ставляться перед публічними службовцями в правоохоронній сфері (передусім в Національній поліції), стають дедалі більш складними, багатогранними та відповідальними [20], що обумовлює потребу в підвищенні вимоги до відповідних публічних службовців. Саме тому посилюються вимоги щодо добору й відбору публічних службовців, 
завдяки чому на публічну службу потрапляють найбільш конкурентоздатні, добросовісні та відповідальні особи.

4. Форми призначення на посаду публічної служби у правоохоронній сфері та заміщення цієї посади, розстановки кадрів. Призначення на посаду $\epsilon$ особливою формою кадрового забезпечення публічної служби в правоохоронній сфері, якій приділяється досить широка увага українських вчених. Причому призначенням на посаду публічної служби у правоохоронній сфері слід розуміти юридичне оформлення (закріплення) адміністративноправового посадового статусу публічного службовця органу публічної служби в правоохоронній сфері, що регламентується чинним законодавством і виявляється у формі розпорядчого документа (наказу, указу, постанови). Що ж стосується заміщення посади, то ним $є$ фактичний юридично значущий спосіб набуття громадянином, призначеним на посаду, відповідного адміністративно-правового статусу, оформленого призначенням.

5. Форми кадрового забезпечення, що стосуються процесу проходження служби в органах публічної служби у правоохоронній сфері. Ця група форм $є$ найбільш об’ємною (об’єднує не лише низку окремих форм кадрового забезпечення, а й їхні підгрупи, що мають власну формальну структуру), оскільки стосується різних аспектів кадрового забезпечення публічної служби, ускладнених проблематикою та особливостями перебігу службових відносин, що $\epsilon$ особливо складними публічно-правовими відносинами за участю публічних службовців (зокрема, можливостями суміщення посад, переміщення, вертикальної та горизонтальної ротації кадрів, службового просування службовців, проведення службового розслідування, перебування службовців у відпустках, передбачених спеціальним законодавством про відпустки тощо).

А. М. Клочко, аналізуючи кадрове забезпечення ОВС, зазначає, що оцінювання службової діяльності персоналу- це один 3 найважливіших напрямів кадрового забезпечення OBC, який $є$ діяльністю керівництва ОВС, що полягає в аналізуванні роботи кожного члена колективу, зіставленні результатів праці 3 встановленими стандартами. У межах цієї форми забезпечення об’єктивується можливість: а) виявляти працівників, котрі не виконують поставлені перед ними задачі в необхідному обсязі та надати їм змогу виправити свої помилки; б) виявляти та заохочувати працівників, що сумлінно виконують свої обов'язки, користуються авторитетом, мають значні успіхи в службовій діяльності, заслуговують на підвищення або переміщення на посаду з більш відповідальними функціональними обов'язками [21, с. 179].

Що ж стосується процедур кадрового забезпечення в межах розглядуваної форми кадрового забезпечення публічної служби в правоохоронній сфері держави, то в цьому контексті слід зауважити, що вони здебільшого відображаються в процедурно-процесуальній діяльності компетентних суб'єктів відносно оцінювання ефективності відповідних кадрів публічної служби та ефективності їх діяльності, контролю за цією діяльністю. Найбільшої уваги серед цих процедур заслуговує атестація публічних службовців.

6. Форма кадрового забезпечення у вигляді припинення службових відносин з публічними службовцями у правоохоронній сфері (припинення публічної служби). Припиненням публічної служби в загальному значенні можна вважати відмову державного службовця від державно-службових повноважень або відмову суб'єкта призначення державному службовцю в 
державно-службових повноваженнях. Причому, як зазначає українська вчена Ю. Г. Фаєр, на відміну від припинення трудового договору, у разі припинення державної служби сторони мають чітко дотримуватися законодавчих приписів і не можуть здійснювати припинення за взаємною згодою без відповідного правового визначення [22, с. 14].

Висновки. Таким чином, кадрове забезпечення публічної служби у правоохоронній сфері характеризується значною кількістю форм кадрового забезпечення i процедур кадрового забезпечення, що здійснюються відповідно до порядку, закріпленого в законодавстві, у межах вказаних форм, об’єктивуючи їх у юридично значущій практичній дійсності. Наявність окресленого обсягу форм і процедур кадрового забезпечення дозволяє формувати публічну службу у правоохоронній сфері таким чином, щоб органи публічної служби відповідної сфери могли оптимально використовувати власний потенціал для досягнення мети свого створення та функціонування, реалізуючи свої завдання.

Форми кадрового забезпечення публічної служби в правоохоронній сфері України - це об’єктивні конструктивні вияви взаємоузгодженого функціонування складових елементів механізму кадрового забезпечення публічної служби у відповідній сфері, що відображають сутність, цілі, завдання, зміст та особливості належного функціонування цих органів, а також спрямовані на перетворення закріплених у нормативно-правових актах вимог щодо здійснення кадрового забезпечення в практичну дійсність.

Форми кадрового забезпечення публічної служби в правоохоронній сфері - це об'єктивні конструктивні вияви взаємоузгодженого функціонування складових механізму кадрового забезпечення публічної служби у відповідній сфері, що відображають сутність, завдання, зміст й особливості належного функціонування цих органів, а також спрямовані на перетворення закріплених у нормативно-правових актах вимог щодо здійснення кадрового забезпечення в практичну площину. У цьому контексті процедури кадрового забезпечення публічної служби в правоохоронній сфері $є$ встановленими адміністративним законодавством публічно-правовими порядками, якими регламентують діяльність публічної служби у відповідній сфері й формують високоефективний та кваліфікований кадровий склад цієї публічної служби, а також забезпечують права, свободи й законні інтереси суб'єктів кадрового забезпечення шляхом здійснення компетентним суб'єктом комплексу дій і заходів, прийняття та виконання управлінських рішень у відповідних межах.

На підставі зробленого нами дослідження, можні дійти висновку, що до основних форм кадрового забезпечення публічної служби в правоохоронній сфері належать:

1) група форм стратегічної організаційно-штатної роботи, яка охоплює: облік кадрового складу; планування кадрового складу (потреби в кадрах) публічної служби в правоохоронній сфері; розподіл штатної чисельності між органами й підрозділами та їі перерозподіл за необхідності (зміна оперативної обстановки, реорганізація служби тощо); стимулювання належної службової активності кадрів, посилення виховного впливу та зміцнення службової дисципліни, законності й поваги прав людини та людської гідності, а також підвищення рівня позитивної відповідальності в діяльності публічної служби. У межах групи форм стратегічної організаційноштатної роботи 3 кадрового забезпечення реалізується низка кадрових процедур, зокрема: процедури розрахунку кадрової чисельності публічної служби; процедури позитивного стимулювання публічної служби; 
2) група навчально-підготовчих форм кадрового забезпечення, яка передбачає: відбір кандидатів на навчання до закладів вищої освіти із специфічними умовами навчання; перебіг процесу навчання; завершення процесу навчання, позитивні результати якого визначають подальший розподіл випускника до держоргану. Основними кадровими процедурами, що здійснюють у межах цієї групи форм кадрового забезпечення, є добір кандидатів на навчання в закладі освіти, а також направлення та зарахування цих кандидатів, подальше навчання й екзаменування здобувачів освіти;

3) група форм добору та відбору публічних службовців, що охоплює відповідні форми кадрового забезпечення, у яких здійснюють різні кадрові процедури, основними з яких є процедури конкурсного відбору персоналу;

4) група форм призначення на вакантну посаду та заміщення цієї посади, розстановки кадрів, що визначена відповідними формами кадрового забезпечення, у межах яких здійснюють різні кадрові процедури, основними з них є: процедура приведення до присяги та складання присяги; процедура прийняття розпорядчого документа про призначення на посаду;

5) група форм, що стосуються процесу проходження служби, а саме: оцінювання ефективності роботи публічних службовців і контролю за виконанням ними службових обов'язків (основною кадровою процедурою $\epsilon$ атестація публічних службовців); підвищення кваліфікації, професіоналізму та перепідготовки кадрів, яка передбачає такі основні підформи кадрового забезпечення: післядипломна освіта публічних службовців (кадрові процедури, пов'язані з реалізацією спеціалізації, перепідготовки, підвищення кваліфікації, стажування службовців); обмін співробітниками й експертами в правоохоронній сфері;

6) група форм кадрового забезпечення у вигляді припинення службових відносин з публічними службовцями у правоохоронній сфері (припинення публічної служби).

Отже, кадрове забезпечення публічної служби в правоохоронній сфері України, власне, як і будь-який інший складний соціально-правовий феномен у площині функціонування суб'єктів публічної адміністрації, підлягає ретельному адміністративно-правовому врегулюванню, в межах якого нормотворцем визначаються особливі правові вимоги до здійснення кадрового забезпечення публічної служби відповідної сфери.

\section{СПИСОК ВИКОРИСТАНИХ ДЖЕРЕЛ}

1. Іванищук А. А. Адміністративно-правове забезпечення судової влади в Україні: дис. ... д-ра юрид. наук. Київ, 2017. 466 с.

2. Мамчур Д.В. Адміністративно-правові засади забезпечення транспортної дисципліни в державі: автореф. дис. ... канд. юрид. наук. Київ, 2010.19 c.

3. Гаспарян С. Г. Адміністративно-правові засади кадрового забезпечення судово-експертних установ України: автореф. дис. ... канд. юрид. наук. Харків, 2019. 20 с.

4. Гальонкін С. А. Адміністративно-правове забезпечення апеляційного провадження в Україні: дис. ... канд. юрид. наук. Суми, 2018. 232 с.

5. Тетеря В.M. Адміністративно-правові засади кадрового забезпечення Національної поліції України на регіональному рівні: автореф. дис. ... канд. юрид. наук. Київ, 2018. 22 с. 
6. Андренко С. О. Адміністративно-правові засади кадрового забезпечення органів внутрішніх справ України: автореф. дис. ... канд. юрид. наук. Харків, 2015. 22 с.

7. Грітчіна В.Ю. Адміністративно-правове забезпечення кадрових процедур в Національній поліції України: автореф. дис. ... канд. юрид. наук. Київ, 2017. 18 с.

8. Галіцина Н. В. Адміністративна процедура як інститут адміністративного процесу. Форум права. 2010. № 4. С. 163-177.

9. Басов А.В. До питання про визначення поняття «юридична процедура». Вісник Академії митної служби України. 2011. № 2. С. 17-22.

10. Плахотнюк Н. Г. Повноваження керівника органу виконавчої влади у сфері управління персоналом. Університетські наукові записки. 2007. № 1. C. 170-177.

11. Кодекс адміністративного судочинства України: Закон України від 06.07.2005 p. № 2747-IV. URL: https://zakon.rada.gov.ua/laws/show/2747-15\#Text.

12. Грищук А. Б. Державна служба в Україні: адміністративноправовий вимір: монографія. Львів: Львів держ ун-т внутр. справ, 2018. 232 с.

13. Галкін Д. В. Організаційно-штатна робота у міліції Радянської України. Право і безпека. 2009. № 5. С. 33-36.

14. Козицький В.І. Поняття та місце регіональних управлінь МВС України в областях у сучасній організаційній структурі органів внутрішніх справ України. Право і безпека. 2011. № 5. С. 68-73.

15. Стародубцев А. А. Професійний відбір на службу до органів внутрішніх справ України. Право і безпека. 2011. № 4. С. 180-184.

16. Корсун С. I. Проблеми професійного відбору працівників правоохоронних органів. Проблеми сучасної психології. 2013. Вип. 19. С. 302-313.

17. Дем'яненко О.С. Роль і значення відомчих навчальних закладів MBC у підготовці кадрів для Національної поліції України. Реформування правової системи в контексті євроінтеграційних процесів: матеріали II Міжнар. наук.-практ. конф.: у 2 ч. (Суми, 18-19 трав. 2018 р.) / [редкол.: А. М. Куліш, О. М. Рєзнік]. Суми: Сумський держ. ун-т, 2018. Ч. 2. С. 175-178.

18. Сокуренко В. В. Перспективні напрями оптимізації процесу відбору кандидатів на навчання до закладів вищої освіти із специфічними умовами навчання, що готують поліцейських. Підготовка поліцейських в умовах реформування системи МВС України: зб. наук. пр. Харків: Харківський нац. унт внутр. справ, 2018. С. 44-47.

19. Венедіктов В. С., Іншин М. І. Сутність та основні напрямки кадрової політики в сфері державної служби. Форум права. 2005. № 1. С. 4-8.

20. Перепелиця А. В. Особливості професійного відбору персоналу до органів внутрішніх справ. Наук. вісн. Львівського держ. ун-ту внутр. справ. 2008. № 2. C. 1-9.

21. Клочко А. М. Кадрове забезпечення органів внутрішніх справ України: порядок та основні елементи. Форум права. 2014. № 4. С. 175-180.

22. Фаєр Ю.Г. Припинення державної служби як інститут адміністративного права: автореф. дис. ... канд. юрид. наук. Одеса, 2015. 20 с. 


\section{P. Komirchyi}

\section{FORMS AND PROCEDURES FOR PERSONNEL PROVISION OF PUBLIC SERVICE IN THE LAW ENFORCEMENT SPHERE}

The article notes that in modern conditions, the place of staffing of the public service in the law enforcement sphere is of fundamental importance, which is studied through the prism of recent changes in the administrative legislation of Ukraine as a new stage in the reform of the law enforcement system of our state. It has been substantiated that the organization of public service in modern conditions presupposes a significant number of interrelated forms and procedures of staffing. The appropriate forms include: the definition of a strategy for organizational and staff work; educational and preparatory work; selection and selection of personnel; appointment and replacement of posts, placement of personnel; ensuring the passage of service. It has been established that the forms of staffing determine the boundaries of the corresponding staffing procedures. The specifics of staffing procedures implemented within the framework of the specified forms of staffing (for example, within the framework of strategic organizational and staff work, procedures for calculating the staffing of the public service, positive incentives for this service, etc.) are established and characterized. It has been theoretically proved that the correct combination of available forms and procedures for staffing contributes to a real increase in the efficiency of the functioning of law enforcement agencies based on the qualitative use of the potential of employees without increasing the time and resources spent on their maintenance. It was determined that the staffing of the public service in the law enforcement sphere of Ukraine is an element of personnel management of public service bodies in the field of order protection, which is a normatively ordered system of interrelated elements that are in stable administrative and legal relations with each other in relation to staffing, within which their functioning as a whole. It is concluded that the forms and procedures for staffing the public service in the law enforcement sphere of Ukraine, in fact, like any other complex social and legal phenomenon in the plane of the functioning of public administration entities, is subject to careful administrative and legal regulation, within which legislators determine special legal requirements for the implementation of staffing of the public service in the relevant field. That is, a large number of requirements are put forward for the existence of staffing in the public service in the law enforcement sphere in a static and dynamic form at the normative level, aimed at properly staffing the subject of public administration with high-quality personnel, making effective and rational staffing management and increasing the level of uniqueness of this phenomenon. A special place among these regulatory requirements is occupied by the regulatory requirements for the organizational structure of the staffing of the public service in the law enforcement sphere.

Keywords: personnel, staffing, public service, forms and procedures, law enforcement, National Police. 